\title{
BIODEGRADATION OF PETROLEUM HYDROCARBONS IN HYPERSALINE ENVIRONMENTS
}

\author{
Luiz Fernando Martins ${ }^{1^{*}}$; Raquel Silva Peixoto ${ }^{2}$
}

${ }^{1}$ Centro de Pesquisas e Desenvolvimento Leopoldo Américo Miguez de Mello, Petrobras, Rio de Janeiro, RJ, Brasil; ${ }^{2}$ Laboratório de Ecologia Microbiana Molecular, Instituto de Microbiologia Professor Paulo de Góes, Universidade Federal de Rio de Janeiro,

Rio de Janeiro, RJ, Brasil.

Submitted: September 27, 2011; Returned to authors for corrections: December 07, 2011; Approved: June 07, 2012.

\begin{abstract}
Literature on hydrocarbon degradation in extreme hypersaline media presents studies that point to a negative effect of salinity increase on hydrocarbonoclastic activity, while several others report an opposite tendency. Based on information available in the literature, we present a discussion on the reasons that justify these contrary results. Despite the fact that microbial ability to metabolize hydrocarbons is found in extreme hypersaline media, indeed some factors are critical for the occurrence of hydrocarbon degradation in such environments. How these factors affect hydrocarbon degradation and their implications for the assessment of hydrocarbon biodegradation in hypersaline environments are presented in this review.
\end{abstract}

Key words: hydrocarbon biodegradation; halophile; hypersaline environment; halophilic/halotolerant hydrocarbon-degraders.

\section{INTRODUCTION}

Hypersaline environments characteristically present salt concentrations higher than 35 g.L $\mathrm{L}^{-1}$ (seawater salinity) (17) and can be established by either natural or anthropic forces that favor salt deposition and accumulation. Therefore, this definition includes a broad range of aquatic and terrestrial environments, with salinities up to saturation $\left(\sim 350\right.$ g.L $\left.{ }^{-1}\right)$ and different salt compositions.

Although high salt concentrations constitute a stressful agent for most of the known living organisms $(16,45)$, hypersaline environments can harbor functional and taxonomical diversified biological communities $(34,35)$. The organisms that grow best in these environments are called halophiles, while the ones whose optimal growth occur in nonsaline media but are able to grow under hypersaline conditions are indicated as halotolerant organisms (19).

Algae of the genus Dunaliella are the producers in saturated or closed to saturation media (salinities higher than $200-250$ g. $\left.L^{-1}\right)$, where they support heterotrophic communities composed mainly by archaea (Family: Halobacteriaceae) and Salinibacter ruber (Bacteria, Order Bacteroidetes) $(35,36)$. Cyanobacteria respond for most of the primary production in aquatic environments with salinities up to $25 \%$ (36) and support essentially bacterial communities (30, 31,32 ). Biological productivity can be quite high in aquatic hypersaline environments and, therefore, hypersaline sediments tend to accumulate high amounts of organic matter, including 
hydrocarbons (14).

Scientific and technical knowledge on halophilic and halotolerant microorganisms have been improved because of increasing perspectives of their application in industrial production bioprocesses, hypersaline wastewater treatments and also basic evolutionary studies, since the oldest fossil microorganisms are found in stromatolites, sedimentary structures similar to contemporary microbial mats found in hypersaline environments (17). On the other hand, literature about hydrocarbon degradation by halophilic and halotolerant microorganisms is still scarce, notwithstanding the importance of this subject for several issues related to petroleum industry: reclamation of oil and brine impacted soils, remediation of oil polluted hypersaline lakes, treatment of oily hypersaline wastewater and hydrocarbon degradation processes in hypersaline petroleum reservoirs.

In a recent review on organic pollutants degradation by halophilic prokaryotes LeBorgne et al. (17) demonstrated that the results about hydrocarbon degradation under high salt concentrations can differ: while some reports point to a negative influence of salinity on hydrocarbonoclastic activity, others show an opposite tendency. In the present work we propose a discussion about the reasons that could justify such differences and indicate the main factors affecting petroleum hydrocarbons biodegradation in hypersaline environments.

\section{EFFECT OF SALINITY ON HYDROCARBONS BIODEGRADATION}

Hydrocarbonoclastic activity in non-saline soils $(25,26,38)$ and groundwater (43) is impaired when salinity increases, since microbial communities in such environments are not expected to be previously adapted to high salt concentrations (20). MinaiTehrani et al. (25) observed $41 \%$ crude oil degradation in soil samples with no $\mathrm{NaCl}$ added, while only $12 \%$ was obtained in samples from the same soil subject to 50 g.L $\mathrm{L}^{-1} \mathrm{NaCl}$ after 120 days (Table 1).

The negative impact of increasing salinity on hydrocarbons biodegradation is also observed in environments where halotolerant and/or slightly halophilic microorganisms tend to be dominant, as the case of mangroves $(11,39)$ and intertidal microbial mats (1). Abed et al. (1) investigated microbial mats from an Arabian Gulf area chronically exposed to oil spills and subject to high daily salinity and temperature fluctuations: 50 g.L $\mathrm{L}^{-1}$ salts and $25{ }^{\circ} \mathrm{C}$ (high tide) to 150 g. $\mathrm{L}^{-1}$ and $40{ }^{\circ} \mathrm{C}$ (low tide). The authors (1) evaluated the degradation rates of several hydrocarbons under a range of salinities: $0 ; 35 ; 50 ; 80 ; 120$ and 160 g. $\mathrm{L}^{-1}$. They reported that almost $100 \%$ of initial phenanthrene and dibenzothiophene were degraded at 35 g.L $\mathrm{L}^{-1}$, while the best degradation results for pristane (approximately 75\%) and $n$ octadecane (around 85\%) occurred between salinities of 35 and 80 g.L $\mathrm{L}^{-1}$ (Table 1). Díaz et al. (11) assessed hydrocarbon biodegradation capability of a mangrove microbial consortium immobilized onto polypropylene fibers. They verified that alkanes biodegradation was lower than $40 \%$ in medium with 0 g.L $\mathrm{L}^{-1} \mathrm{NaCl}$, around $50 \%$ at 20 g. $\mathrm{L}^{-1}$, reaching $65 \%$ (highest biodegradation obtained) at 40 g. $\mathrm{L}^{-1}$. At salinities ranging from 60 to 140 g. $\mathrm{L}^{-1}$ alkanes biodegradation rates were $50-60 \%$, falling to less than $30 \%$ at 180 g.L ${ }^{-1}$ (Table 1).

Even in typical hypersaline environments a negative impact on hydrocarbon biodegradation induced by increasing salinity has been reported. Ward and Brock (44) observed that the negative effect of salinity increase was pronounced on hexadecane biodegradation, more than on glutamate biodegradation. These authors collected samples (salinity range: $33-284$ g. $\mathrm{L}^{-1}$ ) from the water column at Great Salt Lake and at shores of various evaporation ponds nearby. It was observed that hexadecane mineralization $\left(\mathrm{CO}_{2}\right.$ production) decreased from $50 \%$ at 33 g. $\mathrm{L}^{-1}$ salts $(<150 \mathrm{~h})$ to negligible values at salinities higher than 250 g.L $\mathrm{L}^{-1}$ (Table 1), while glutamate mineralization was $68 \%$ at salinity of 33 g.L $\mathrm{L}^{-1}(143 \mathrm{~h})$ and $54 \%$ at 284 g.L $\mathrm{L}^{-1}$ salts $(450 \mathrm{~h})$. These mineralization results were very consistent with data about microbial growth in enrichment media for hydrocarbonoclastic aerobic bacteria: no growth was observed at salinities higher than 250 g. $\mathrm{L}^{-1}$.

Nevertheless, Bertrand et al. (6) isolated from interface water sediment with salinity of 310 g.L $L^{-1}$ (31\%) a strain of a halophilic archaeon, recently classified as Haloarcula vallismortis (41) (labeled EH4 by Bertrand et al. (6)), that degraded hydrocarbons more efficiently at the highest salinities tested. Eicosane biodegradation percentage increased from $\sim 10 \%$ in medium with 
146 g. $\mathrm{L}^{-1} \mathrm{NaCl}$ to a $64 \%$ at 204 g. $\mathrm{L}^{-1} \mathrm{NaCl}, 30$ days incubation (Table 1). Such haloarchaeon presented optimal growth at $45{ }^{\circ} \mathrm{C}$ and capability to degrade a few aliphatic and aromatic hydrocarbons (Table 2), especially tetradecane, whose initial concentration decreased $88 \%$ after 30 days (6).

Indeed, several hydrocarbonoclastic halophilic and halotolerant microorganisms have been isolated from chronically hydrocarbon impacted sites and petroleum industry facilities, most of them affiliated to the class Gammaproteobacteria $(10,13,17$, 27, 28, 40, 46) (Table 2). Marinobacter hydrocarbonoclasticus is an extreme halotolerant (4,7 to 204 g. $\mathrm{L}^{-1} \mathrm{NaCl}$, optimal growth at 35 g. $\mathrm{L}^{-1} \mathrm{NaCl}$ ) able to use a lot of hydrocarbons as only carbon and energy sources, especially intermediate chain length aliphatics $(5,13)$. Mnif et al. (27) obtained from saline wastewater samples collected in a petroleum rig a Halomonas strain adapted to grow in media with crude oil, diesel, lubricant oil or hexadecane as the only carbon sources. Although the optimal growth range for this strain was between 50 and 80 g. $\mathrm{L}^{-1}$, it was shown its ability in maintaining a basal hydrocarbonoclastic metabolism in media with up to 140 g.L $\mathrm{L}^{-1}$ salts. Other Gammaproteobacteria's representatives isolated from sites impacted by petroleum industry activities were capable to completely degrade monoaromatic compounds in one to two weeks at salinities of 140 to 230 g.L $\mathrm{L}^{-1}(28,40)$, or up to five weeks at 290 g.L. $\mathrm{L}^{-1}(40)$.

Table 1. Summary of reports regarding salinity influence on hydrocarbon biodegradation cited throughout this review.

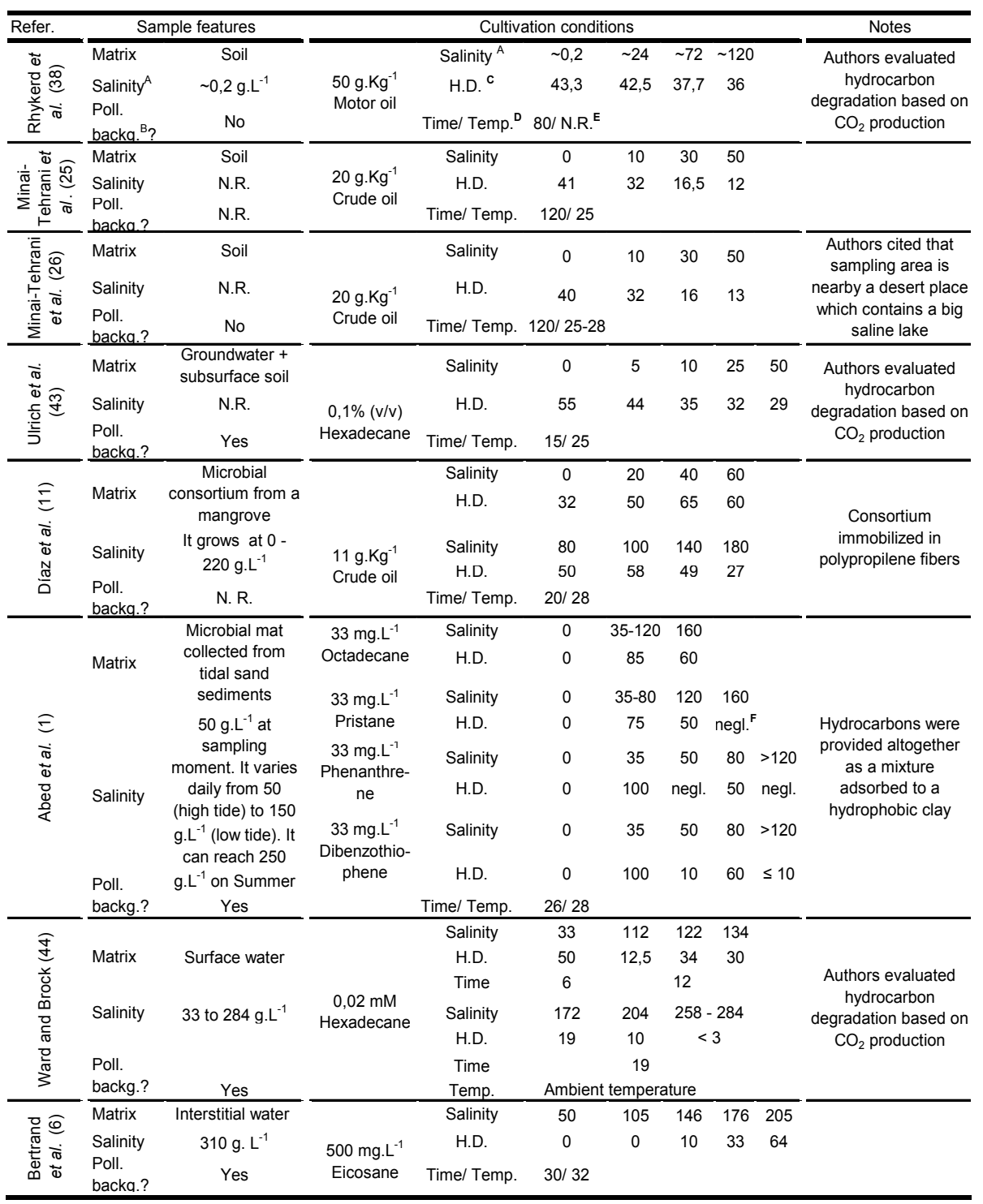

${ }^{\text {A }}$ Salinity values expressed in $\mathrm{g} . \mathrm{L}^{-1} \mathrm{NaCl}$; some original papers used different units, which were converted to be reported in this review.; ${ }^{\mathrm{B}}$ Poll. backg. $=$ Pollution background; ${ }^{\mathrm{C}}$ H.D. $=$ hydrocarbon concentration decrease, expressed in \%; ${ }^{\mathrm{D}}$ Time expressed in days; temperature (Temp.) in ${ }^{\circ} \mathrm{C} ;{ }^{\mathrm{E}}$ N.R. $=$ not reported; ${ }^{\mathrm{F}}$ negl. $=$ negligible 
More examples of hydrocarbon-degrading haloarchaea have been reported recently (Table 2). Al-Mailem et al. (4) isolated from a sabkha on the coast of Arabian Gulf four strains of haloarchaea (Haloferax (two), Halobacterium and Halococcus) able to degrade several aliphatic and aromatic hydrocarbons, with biodegradation rates increasing as salinities increased through 58 to 175 g.L $\mathrm{L}^{-1} \mathrm{NaCl}$.

Zvyagintseva et al. (47) evaluated hydrocarbonoclastic activity by Dietzia maris, an actinobacterium, at salinities of 5 to 100 g. $\mathrm{L}^{-1} \mathrm{NaCl}$. Optimal biodegradation occurred at 50 to 100 g.L. $\mathrm{L}^{-1} \mathrm{NaCl}$ : paraffins $\left(\mathrm{C}_{14}-\mathrm{C}_{18}\right)$ were degraded at 70 and 100 g. $\mathrm{L}^{-1} \mathrm{NaCl}$ slower than at 50 g. $\mathrm{L}^{-1}$, however, all these media presented equivalent amounts of $\mathrm{CO}_{2}$ after seven days. Among the halophilic fungi, Fusarium lateritium and
Drechslera sp. were shown to metabolize crude oil, with degradation efficiency improved more than thrice if petroleum was an additional source of carbon and energy instead of being the exclusive one (29).

The works on the influence of salinity on petroleum hydrocarbons degradation cited in this review are summarized in Table 1. Table 2 presents a summary of the reports on halophilic/halotolerant hydrocarbon-degraders cited herein. It has been evidenced that impairment to hydrocarbonoclastic activity at high salinities (44) can not be attributed only to osmotic stress on metabolic activity of native microorganisms or to absence of hydrocarbon catabolism among halophiles. So, how to explain the divergence of conclusions observed in literature on hydrocarbon biodegradation at high salinities?

Table 2. Halophilic and halotolerant hydrocarbon-degraders and the hydrocarbons these microorganisms proved to degrade.

\begin{tabular}{|c|c|c|c|c|}
\hline Microorganism & $\begin{array}{l}\text { Hydrocarbon pollution } \\
\text { background? }\end{array}$ & $\begin{array}{l}\text { Salinity }\left(\mathrm{g} . \mathrm{L}^{-1}\right) \text { applied } \\
\text { in biodegradation assay }\end{array}$ & Hydrocarbons shown to be metabolized & Reference \\
\hline $\begin{array}{l}\text { Haloferax } \mathrm{sp} . \mathrm{HA}-1 \\
\text { Haloferax sp. HA-2 } \\
\text { Halobacterium } \mathrm{sp} . \\
\text { Halococcus } \mathrm{sp} .\end{array}$ & $\begin{array}{l}\text { Yes, despite low hydrocarbon } \\
\text { concentration measured }\end{array}$ & 175 & Crude oil, Octadecane, Phenanthrene & 4 \\
\hline $\begin{array}{l}\text { Marinobacter } \\
\text { hydrocarbonoclasticus } \\
\text { SP.17 }\end{array}$ & Yes & 35 & $\begin{array}{c}\text { Tetradecane, Hexadecane, Heneicosane, } \\
\text { Pristane } \\
\text { Phenanthrene, Phenyldecane }\end{array}$ & 5 and 13 \\
\hline $\begin{array}{l}\text { Haloarcula } \\
\text { vallismortis* }\end{array}$ & Presumably yes & 310 & $\begin{array}{c}\text { Tetradecane, Hexadecane, Eicosane, } \\
\text { Heneicosane, Pristane } \\
\text { Acenaphthene, Phenanthrene, Anthracene, } \\
\text { Methyl anthracene }\end{array}$ & 6 \\
\hline $\begin{array}{l}\text { Ten strains of } \\
\text { Haloarchaea }\end{array}$ & Presumably not & 200 & $\begin{array}{c}\text { Naphthalene, Anthracene, Phenanthrene, } \\
\text { Pyrene, Benzo(a)anthracene }\end{array}$ & 7 \\
\hline $\begin{array}{l}\text { Fundibacter jadensis } \\
\text { T9T }\end{array}$ & Not informed & 35 & Tetradecane, Hexadecane, Pristane & 10 \\
\hline Halomonas sp. & Produced water & 100 & Crude oil $\left(\mathrm{C}_{11-} \mathrm{C}_{22}\right)$, Hexadecane & 27 \\
\hline $\begin{array}{l}\text { Consortium of } \\
\text { Marinobacter sp. } \\
\text { strains }\end{array}$ & Yes & 146 & Benzene, Toluene, Ethybenzene, Xylenes & 28 \\
\hline $\begin{array}{l}\text { Fusarium lateritium } \\
\text { Drechslera } \mathrm{sp} .\end{array}$ & Presumably yes & 100 & Crude oil & 29 \\
\hline $\begin{array}{c}\text { Consortium } \\
\text { Gammaproteobacteria } \\
+ \text { Bacteroidetes } \\
\end{array}$ & Yes & 292 & Benzene, Toluene & 40 \\
\hline $\begin{array}{c}\text { Haloarcula } \\
\text { argentinensis } \\
\text { Haloferax volcanii } \\
\text { Haloferax alexandrinus } \\
\text { Haloferax volcanii } \\
\end{array}$ & No & 225 & $\begin{array}{c}\text { Heptadecane } \\
\text { Heptadecane } \\
\text { Heptadecane, Phenanthrene } \\
\text { Heptadecane, Eicosane }\end{array}$ & 41 \\
\hline $\begin{array}{l}\text { Alcanivorax } \\
\text { borkumensis }\end{array}$ & Presumably yes & 35 & Hexadecane & 46 \\
\hline Dietzia maris & Not informed & $5-100$ & Mixture of n-alkanes: $\mathrm{C}_{14}-\mathrm{C}_{18}$ & 47 \\
\hline
\end{tabular}

* Bertrand et al. (6) labeled this strain as EH4 and assigned it to Halobacterium sp. based on phenotypic features. Recently, Tapilatu et al. (41) re-assigned it to Haloarcula vallismortis based on $16 \mathrm{~S}$ rRNA. 


\section{CONSIDERATIONS ABOUT HYDROCARBON BIODEGRADATION AT HIGH SALINITIES}

The effect of salinity on microbial hydrocarbonoclastic activity depends on the amplitude variation of salt concentration imposed to and on the salinity of the habitat of the microorganisms under investigation. In Abed et al. (1) and Díaz et al. (11) studies, it is clear that very low salt concentrations reduce hydrocarbonoclastic activity and the optimal biodegradation results are reached within moderate salinity ranges. In the case of Bertrand et al. (6) it was necessary to use extreme salinity conditions because the strain under investigation was a halophilic archaeon isolated from an extreme hypersaline environment. However, Ward and Brock (44) worked with samples from hypersaline environments as well. Besides, these authors mentioned that their study site (Great Salt Lake) had been affected by petroleum and it can be supposed that the sampling site of Bertrand et al.'s report (6) also presented oil pollution background, since it was located in the vicinity of an urban area (Aigues-Mortes, France) and because eicosane, heneicosane and pristane were detected in water samples collected from there. Why the tendencies about salinity effect on hydrocarbon biodegradation observed by Ward and Brock (44) were opposite to the ones presented by Bertrand

et al. (6)?

First of all, it is necessary to consider that hydrocarbons are less bioavailable in hypersaline environments than in nonsaline ones. This is a consequence of the "salting out" effect: because soluble salts reduce hydrophobic organic compounds solubility in water, the higher the salts concentration in aqueous phase the higher the tendency of organic compounds to be adsorbed to the solid matrix (sediment or soil) $(18,24$, $42)$.

This effect of salinity on hydrocarbons solubility is mentioned by Margesin and Schinner in a review about biodegradation of hydrocarbons by extremophiles (20) and is appointed by McGenity (23) as a reason for the low number of known halophilic hydrocarbon degraders. Means (24) suggests that polyaromatic hydrocarbons sorption to the sediment particles increases in the presence of salts, not only because the salting out effect on such hydrocarbons but also because the salting out effect on the organic phase of the sediment, turning it into a better solvent for the polyaromatics. This explanation is reinforced by Turner \& Rawling's conclusions (42), which point to an enhancement of hydrophobicity or solvency of the sediment organic matter through interactions between organic matter and seawater cations.

Salting out effect on hydrocarbons could justify the low rates of hexadecane biodegradation observed by Ward and Brock (44) at the highest salty samples. Since these authors sampled from the water column they probably dealt with microbial populations that had not been submitted to hydrocarbons selection pressure, since the hydrocarbons were expected to be adsorbed to the sediments at their study site.

Bertrand et al. (6), on the other hand, collected interstitial water from the sediment and probably obtained samples with microorganisms which had been directly exposed to the hydrocarbon polluted sediment and, consequently, were adapted to metabolize hydrocarbons.

Other important aspect that could be taken into account to comprehend the opposite conclusions between these studies is the laboratory growth conditions. In extreme hypersaline environments (204 to 286 g. $\mathrm{L}^{-1}$ in Ward and Brock (44); 310 g. $\mathrm{L}^{-1}$ in Bertrand et al. (6)) halophilic archaea constitute the dominant populations $(33,34,36)$, whose optimal temperature range is generally higher than $35^{\circ} \mathrm{C}(9)$. We can suppose that temperatures used by Ward and Brock (44) had probably impaired archaea growth since they reported applying ambient temperature.

Despite the fact that several studies have been reporting the presence of hydrocarbon-degraders in hypersaline environments, we do not know in which extent the halophilic biodegradation of petroleum hydrocarbons does occur in situ. High salinities restrict not only microbial access to hydrocarbons but also the availability of oxygen, since its 
solubility decreases as salt concentration increases $(23,37)$. This fact makes studies on anaerobic biodegradation of hydrocarbons by halophiles critical for the comprehension of hydrocarbonoclastic activity in hypersaline environments, but there is a lack of such studies (23). It is important to bring to attention that all the reports summoned in this review refer to results obtained under laboratory conditions, in which hydrocarbons and oxygen can be easily provided.

On the other hand, aquatic hypersaline environments usually present high biological productivity and, therefore, high amount of organic matter, including hydrocarbons, is deposited in evaporitic sediments (14). This fact has even led to the proposal that many of the world's oil reservoirs are formed from hypersaline environments (3). So, it can be inferred that halophiles have been exposed to high hydrocarbons concentrations very long before the advent of petroleum industry era and, consequently, the ability to metabolize hydrocarbons could be an evolutionary acquisition widespread among halophiles more than it was considered by some authors $(23,33)$. This hypothesis is supported by recent studies that report the existence of halophilic prokaryotic populations adapted to degrade petroleum hydrocarbons even in pristine environments, i.e., without oil pollution background (7, 12, 41). Tapilatu et al. (41), for example, obtained from water samples of a salt crystallizer pond $\left(268\right.$ g.L $\left.\mathrm{L}^{-1}\right)$ with no known oil pollution history four strains of halophilic archaea (Haloarcula and Haloferax) able to degrade 32 to $95 \%$ of initial heptadecane concentration in 30 days, growing in complex media with salinities of 225 g.L. $\mathrm{L}^{-1}$. Yet D'Ippólito et al. (12) observed growth and chemotactic response towards hydrocarbons by two strains of Halomonas, one of them from a non-polluted brine. Bonfá et al. (7) evaluated ten strains of haloarchaea isolated from hypersaline habitats presumably with no oil pollution background to degrade a mixture of polyaromatic hydrocarbons and observed that all strains were capable of degrading these compounds at 200 g.L $\mathrm{L}^{-1} \mathrm{NaCl}$. These strains were shown to reduce organic content in produced waters more efficiently than hydrogen peroxide treatment (7).

McGenity (23) highlights the hydrophilic nature of halophiles' cell surface as an obstacle for the metabolism of hydrophobic compounds, but, regarding this scenario, the ability to produce emulsifying agents observed in several hydrocarbon-degrading halophiles $(5,21,22,46)$ might be considered an adaptation to circumvent the problem of access to carbon sources, since emulsifiers increase hydrocarbon availability $(8,15)$.

\section{CONCLUSIONS AND FINAL CONSIDERATIONS}

For assessing the effects of salinity variation on hydrocarbonoclastic activity it is necessary to take into account the sampling sites background regarding petroleum hydrocarbons occurrence (although this last one is not always mandatory) and salt concentrations, as well as sampling strategies and laboratory microbial growth conditions applied, since microbial growth requirements vary according to the dominant halophilic populations.

Increase in salt concentration per se is not necessarily an impediment to petroleum hydrocarbons biodegradation. Instead, microbial hydrocarbonoclastic activity is impacted by fluctuations in salt concentrations either below or beyond the salinity range for optimal growth of the microorganism under investigation. We have to consider that anthropic salinization impairs the hydrocarbonoclastic activity of native nonhalotolerant microorganisms, as well as artificial desalinization is an obstacle for bioremediation of petroleum polluted hypersaline environments.

Hypersalinity is required for hydrocarbon catabolism to be performed in hypersaline environments, but at extreme salinities the salting out effect on hydrocarbons imposes a critical barrier to hydrocarbon biodegradation. Not only the accessibility to carbon sources becomes restricted, but so is the availability of oxygen. In this sense, the presence of halophilic photoautotrophs can be a critical factor for the achievement of hydrocarbon biodegradation (2), since their photosynthetic 
activity could compensate the lack of oxygen imposed by hypersalinity. Higher accessibility to and, consequently, improvement in biodegradation of hydrocarbons in hypersaline conditions were reached through immobilization of microbial cells in polypropilene fibers (11). On the other hand, several halophiles are emulsifier-producers, characteristic that is expected to make possible for the halophiles to access the hydrocarbons instead of the effects of the salts on the hydrocarbons' solubility. In this sense, application of emulsifiers or halophilic emulsifier-producers could be part of a bioremediation strategy.

Hydrocarbon catabolism might be a widespread ability among halophiles because of the typical prolific production and accumulation of biomass in their habitats, but strong support for such hypothesis will come from the efforts in screening for genes encoding hydrocarbonoclastic enzymes within halophilic genomes.

Notwithstanding the expressive biodegradation results presented in this review, attempts to assess petroleum hydrocarbons catabolism by halophilic and halotolerant microorganisms in situ are required to evaluate the extent of such microbial activity in nature, which necessarily implies to fulfill the gap on anaerobic biodegradation of hydrocarbons at high salinities. Comprehension about the aerobic and anaerobic hydrocarbon biodegradation processes in situ will support research on microbial enhanced oil recovery and petroleum degradation in reservoirs.

\section{ACKNOWLEDGEMENTS}

The authors thank J. Medeiros for her grammatical revision of this manuscript. L.F. Martins thanks A. U. Soriano, G. V. Sebastián and J. Medeiros for encouraging the development of this review and PETROBRAS for the support to the research. The authors also thank the reviewer for the suggestions.

\section{REFERENCES}

1. Abed, R.M.M.; Al-Thukair, A.; De Beer, D. (2006). Bacterial diversity of a cyanobacterial mat degrading petroleum compounds at elevated salinities and temperatures. FEMS Microbiol. Ecol., 57, 290-301.

2. Abed, R.M.M.; Köster, J. (2005). The direct role of aerobic heterotrophic bacteria associated with cyanobacteria in the degradation of oil compounds. Int. Biodeterior. Biodegradation 55(1), 29-37.

3. Aizenshtat, Z.; Miloslavski, I.; Aschengrau, D.; Oren, A. (1999). Hypersaline depositional environments and their relation to oil generation. In: Oren, A. (ed). Microbiology and Biogeochemistry of Hypersaline Environments. CRC Press, Boca Raton, p. 89-108.

4. Al-Mailem, D.M. ; Sorkhoh, N.A.; Al-Awadhi, H.; Eliyas, M.; Radwan, S.S. (2010). Biodegradation of crude oil and pure hydrocarbons by extreme halophilic archaea from hypersaline coasts of Arabian Gulf. Extremophiles 14, 321-328.

5. Al-Mallah, M.; Goutx, M.; Mille, G.; Bertrand, J.C. (1990). Production of emulsifying agents during growth of a marine Alteromonas in sea water with eicosane as carbon source, a solid hydrocarbon. Oil Chem. Pollut. 6(4), 289-305.

6. Bertrand, J.C.; Al-Mallah, M.; Acquaviva, M.; Mille, G. (1990). Biodegradation of hydrocarbons by an extremely halophilic archaebacterium. Lett. Appl. Microbiol. 11, 260-263.

7. Bonfá, M.R.; Grossman, M.J.; Mellado, E.; Durrant, L.R. (2011). Biodegradation of aromatic hydrocarbons by Haloarchaea and their use for the reduction of the chemical oxygen demand of hypersaline petroleum produced water. Chemosphere 84(11), 1671-1676.

8. Boopathy, R. (2000). Factors limiting bioremediation technologies. Bioresour. Technol. 74, 63-67.

9. Bowers, K.J.; Wiegel, J. (2009). Temperature and $\mathrm{pH}$ optima of extremely halophilic archaea: a mini-review. Extremophiles 15, 119-128.

10. Bruns, A.; Berthe-Corti, L. (1999). Fundibacter jadensis gen. nov., sp. nov., a new slightly halophilic bacterium, isolated from intertidal sediment. Int. J. Syst. Bacteriol. 49, 441-448.

11. Díaz, M.P.; Boyd, K.G.; Grigson, S.G.W.; Burgess, J.G. (2002). Biodegradation of crude oil across a wide range of salinities by an extremely halotolerant bacterial consortium MPD-M, immobilized onto polypropylene fibers. Biotechnol. Bioeng. 79(2), 145-153.

12. D’Ippólito, S. ; Castro, R.E. ; Seitz, K.H. (2011). Chemotactic responses to gas oil of Halomonas spp. strains isolated from saline environments in Argentina. Rev. Argent. Microbiol. 43(2), 107-110.

13. Gauthier, M.J.; Lafay, B.; Christen, R.; Fernandez, L.; Acquaviva, M.; Bonin, P.; Bertrand, J.C. (1992). Marinobacter hydrocarbonoclasticus gen. nov, sp. nov, a new, extremely halotolerant, hydrocarbon-degrading marine bacterium. Int. J. Syst. Bacteriol. 42(4), 568-576.

14. Javor, B. (1989). Hypersaline environments: microbiology and biogeochemistry. Springer-Verlag, New York.

15. Johnsen, A.R.; Wick, L.Y.; Harms, H. (2005). Principles of microbial PAH- degradation in soil. Environ. Pollut. 133, 71-84.

16. Kargi, F.; Dincer, A.R. (1996). Effect of salt concentration on biological treatment of saline wastewater by fed-batch operation. Enzyme Microb. Technol. 19, 529-537.

17. Le Borgne, S.; Paniagua, D.; Vazquez-Duhalt, R. (2008). Biodegradation 
of organic pollutants by halophilic bacteria and archaea. J. Mol. Microbiol. Biotechnol. 15, 74-92.

18. Mackay, D.; Shiu, W.Y.; Ma, K.C.; Lee, S.C. (2006). Handbook of physical-chemical and environmental fate for organic chemicals. $2^{\text {nd }} \mathrm{ed}$. Taylor \& Francis, Boca Raton.

19. Madigan, M.T.; Martinko, J.M.; Dunlap, P.V.; Clark, D.P. (2009). Brock - Biology of microorganisms. $12^{\text {th }}$ ed. Pearson Benjamin Cummings, New York.

20. Margesin, R.; Schinner, F. (2001). Biodegradation and bioremediation of hydrocarbons in extreme environments. Appl. Microbiol. Biotechnol. 56, 650-663.

21. Margesin, R.; Schinner, F. (2001). Potential of halotolerant and halophilic microorganisms for biotechnology. Extremophiles 5, 73-83.

22. Martínez-Checa, F.; Toledo, F.L.; Vilchez, R.; Quesada, E.; Calvo, C. (2002). Yield production, chemical composition, and functional properties of emulsifier H28 synthesized by Halomonas eurihalina strain H-28 in media containing various hydrocarbons. Appl. Microbiol. Biotechnol. 58(3), 358-363.

23. McGenity, T.J. (2010). Halophilic hydrocarbon degraders. In: K. N. Timmis (ed). Handbook of Hydrocarbon and Lipid Microbiology. Springer-Verlag, Berlin, p.1939-1951.

24. Means, J.C. (1995). Influence of salinity upon sediment-water partitioning of aromatic hydrocarbons. Mar. Chem. 51, 3-16.

25. Minai-Tehrani, D.; Herfatmanesh, A.; Azari-Dehkordi, F.; Minuoi, S. (2006). Effect of salinity on biodegradation of aliphatic fractions of crude oil in soil. Pakistan J. Biol. Sci. 9(8), 1531-1535.

26. Minai-Tehrani, D.; Minuoi, S.; Herfatmanesh, A. (2009). Effect of salinity on biodegradation of polycyclic aromatic hydrocarbons (PAHs) of heavy crude oil in soil. Bull. Environ. Contam. Toxicol. 82, 179-184.

27. Mnif, S.; Chamka, M.; Sayadi, S. (2009). Isolation and characterization of Halomonas sp. strain C2SS100, a hydrocarbon-degrading bacterium under hypersaline conditions. J. Appl. Microbiol. 107, 785-794.

28. Nicholson, C.A.; Fathepure, B.Z. (2004). Biodegradation of benzene by halophilic and halotolerant bacteria under aerobic conditions. Appl. Environ. Microbiol. 70(12), 1222-1225.

29. Obuekwe, C.O.; Badrudeen, A.M.; Al-Saleh, E.; Mulder, J.L. (2005). Growth and hydrocarbon degradation by three desert fungi under conditions of simultaneous temperature and salt stress. Int. Biodeterior. Biodegradation 56, 197-205.

30. Oren, A. (1990). Thymidine incorporation in saltern ponds of different salinities: estimation of in situ growth rates of halophilic archaeobacteria and eubacteria. Microb. Ecol. 19(1), 43-51.

31. Oren, A. (1990). Estimation of the contribution of halobacteria to the bacterial biomass and activity in a solar saltern by the use of bile salts. FEMS Microbiol. Ecol. 73, 41-48.

32. Oren, A. (1990). The use of protein synthesis inhibitors in the estimation of the contribution of halophilic archaebacteria to bacterial activity in hypersaline environments. FEMS Microbiol. Ecol. 73, 187-192.

33. Oren, A. (1992). Microbial degradation of pollutants at high salt concentrations. Biodegradation 3, 387-398.

34. Oren, A. (2002). Diversity of halophilic microorganisms: environments, phylogeny, physiology, and applications. J. Ind. Microbiol. Biotechnol. 28, 56-63.

35. Oren, A. (2008). Microbial life at high salt concentrations: phylogenetic and metabolic diversity. Saline Systems. http://www.salinesystems.org/ content $/ 4 / 1 / 2$.

36. Oren, A. (2009). Saltern evaporation ponds as model systems for the study of primary production processes under hypersaline conditions. Aquat. Microb. Ecol. 56, 193-204.

37. Pfeifer, F.; Krüger, K.; Röder, R.; Mayr, A.; Ziesche, S.; Offner, S. (1997). Gas vesicle formation in halophilic Archaea. Arch. Microbiol. 167, 259-268.

38. Rhykerd, R.L.; Weaver, R.W.; Mcinnes, K.J. (1995). Influence of salinity on bioremediation of oil in soil. Environ. Pollut. 90, 127-130.

39. Santos H.F.; Carmo F.L.; Paes J.E.S.; Rosado A.S.; Peixoto R.S. (2011). Bioremediation of Mangroves Impacted by Petroleum. Water Air Soil Pollut. 216(1-4), 329-350.

40. Sei, A.; Fathepure, B.Z. (2009). Biodegradation of BTEX at high salinity by an enrichment culture from hypersaline sediments of Rozel Point at Great Salt Lake. J. Appl. Microbiol. 107, 2001-2008.

41. Tapilatu, Y.H.; Grossi, V.; Acquaviva, M.; Militon, C.; Bertrand, J.C.; Cuny, P. (2010). Isolation of hydrocarbon-degrading extremely halophilic archaea from an uncontaminated hypersaline pond (Camargue, France). Extremophiles 14, 225-231.

42. Turner, A.; Rawling, M.C. (2001). The influence of salting out on the sorption of neutral organic compounds in estuaries. Water Res. 35(18), 4379-4389.

43. Ulrich, A.C.; Guigard, S.E.; Foght, J.M.; Semple, K.M.; Pooley, K.; Armstrong, J.E.; Biggar, K.W. (2009). Effect of salt on aerobic biodegradation of petroleum hydrocarbons in contaminated groundwater. Biodegradation 20, 27-38.

44. Ward, D.M.; Brock, T.D. (1978). Hydrocarbon degradation in hypersaline environments. Appl. Environ. Microbiol. 35(2), 353-359.

45. Woolard, C.R.; Irvine, R.L. (1994). Biological treatment of hypersaline wastewater by a biofilm of halophilic bacteria. Water Environ. Res. 66(3), 230-235.

46. Yakimov, M.M.; Golyshin, P.N.; Lang, S.; Moore, E.R.B.; Abraham, W.R.; Lünsdorf, H.; Timmis, K.N. (1998). Alcanivorax borkumensis gen. nov., sp. nov., a new, hydrocarbon-degrading and surfactantproducing bacterium. Int. J. Syst. Bacteriol. 48, 339-348.

47. Zvyagintseva, I.S.; Poglazova, M.N.; Gotoeva, M.T.; Belyaev, S.S. (2001). Effect on the medium salinity on oil degradation by nocardioform bacteria. Microbiology 70(6), 652-656. 